\section{JIBM}

Journal of International Business and Management (JIBM) Journal Homepage: https://rpajournals.com/jibm

\title{
Sustainable Corporate Entrepreneurship of Publicly Traded Commercial Banks: A Developing Country Perspective
}

\author{
Md. Rabiul Islam' \\ Md. Abdur Rashid \\ Md. Nuruzzaman ${ }^{3 *}$ \\ Rajshahi University of Engineering and Technology (RUET), Bangladesh \\ Bangladesh Army University of Engineering and Technology (BAUET), Bangladesh ${ }^{2}$ \\ University of Rajshahi (RU), Bangladesh ${ }^{3}$
}

\begin{abstract}
This paper aims to create empirical support about Creating Shared Value (CSV) notion developed by Porter, M.E. and Kramer, M.R. (2011). To accomplish the aim, the study has developed a set of decision rules to recognize banking products or services that can be characterized as Sustainable Corporate Entrepreneurship (SCE). This has been done by reviewing the literature of SCE, CSR, and CSV in the domain. Hereafter, it has made content analysis of annual reports of randomly selected banking corporations in light of the decision rules developed earlier. The purpose is to explain if CSV notion can be used as credible evidence of current SCE practices in the context of developing country like Bangladesh. To attain this purpose, the study has randomly selected 50 percent of the commercial banks out of 30 DSE listed commercial banks in Bangladesh. The study has found that banking corporations are engaged in SCE, though their performances on that are increasing in absolute terms (over the year), not in relative terms (over general investment). Moreover, financial performance remains constant for banks that are engaged exceptionally in SCE. Hence, the findings somewhat support the CSV notion to explain the current practices of SCE.
\end{abstract}

Keywords: Entrepreneurship, Sustainable entrepreneurship, Sustainable corporate entrepreneurship, Corporate social responsibility, Creating shared value, Shared value

\section{*Corresponding author: Md. Nuruzzaman; Email: masumzaman@ru.ac.bd DOI: https://doi.org/10.37227/jibm-2021-09-1498}

\section{Introduction}

Due to globalization, local corporations are also facing sustainability challenges like the multinational corporations do face to effectively do business. Multinational corporations are facing sustainability challenges due to their wide network of suppliers, distributors and affiliates (Wheeler, Fabig \& Boele, 2002). They are facing pressures for sustainability from diverse sources such as environmental protection agencies, NGOs, trade unions and human rights organizations (Wheeler et al., 2002; Bendell, 2004; Jenkins, 2005; Broomhill, 2007). "Large companies, in particular, are responsible for many social and ecological problems, including pollution and devastation of the environment, the abuse of labor and human rights, and the lack of transparency in corporate decisions and practices" (Baltazar, 2011). 
Similarly, Agarwal (2008) maintained that "trade and commerce produces goods and services for the society and in this purpose it not only creates value addition, employment but also pollution and raises unexpected demand for superfluous products which have bad impact on society." Similar to the multinational corporations, banking corporations in the context of developing country like Bangladesh are also facing sustainability challenges because their financing activities can exacerbate negative activities of other corporations.

In this backdrop, Bangladesh Bank (BB)-the central bank of Bangladesh has formulated rules for commercial banks to address sustainable issues. For greater financial inclusion, the $\mathrm{BB}$, in addition to CSR, has directed commercial banks to give priority to some thirst sectors such as agriculture, small \& medium scale enterprises. Besides, the BB has formulated policy so that commercial banks can engage in "mobile financial services, online banking, school banking, agent banking, and environment friendly banking" (Islam, 2018). As a matter of fact, commercial banks earn interest from loans to industry, export-import, real estate, and consumer. The banks also earn money from investing both in treasury bills, bonds and equity shares. Furthermore, the banks earn commission from different services such as brokerage, money exchange, money transfer, remittance collection, utility bills collections in favor of service organizations etc.

In reality, most of the commercial banks were started sustainable issues from a risk point of view and pressures from the central bank. However, very few of them have been able to capitalize the opportunities of sustainability. Many of them were concentrated to perform CSR activities in the form of giveaway a portion of their profit to education, healthcare, sports, and culture. However, with changes of time, commercial banks have also changed their strategy for the financial inclusion of huge number of unbanked people. Keeping in mind to address the unbanked people, they have also innovated their products and services. Their ways of addressing sustainable issues are consistent with the CSV concept of Porter and Kramer (2011). In their popular concept Porter and Kramer (2011) were strategically viewed the corporate sustainability issues and defined CSV as "creating economic value in a way that also creates value for society by addressing its needs and challenges" (p.64). The present study has conceptualized the CSV notion to provide empirical support into it. The objective is to explain if CSV notion can be used as a plausible explanation of current SCE practices of publicly traded commercial banks in Bangladesh.

\section{Entrepreneurship}

\section{Key Issues and Debates}

Entrepreneurship has been viewed by Amit et al., (1993) as "a process that helps in earning profits from novel, distinctive, and valuable combinations of resources in an uncertain environment". Eckhardt (2003) have given a definition of entrepreneurship from the opportunity driven perspective. In their own words, "entrepreneurship is the discovery, evaluation, and exploitation of future goods and services" (p. 336). The prior definition has advanced by Stokes et al. (2010) as "a societal phenomenon or process of change consisting of three behavioral components: (i) the identification, evaluation, and exploitation of an opportunity; (ii) the management of change so as to facilitate the production and consumption of new goods and services; (iii) the creation of through successful exploitation of a new idea" (p.8). The definition of Stokes et al. (2010) is consistent with the purpose of the present study and hereby regarded as the operational definition of entrepreneurship. And hence, corporate entrepreneurship is the study of behaviors and actions of entrepreneurs in an existing corporate setting. 


\section{Corporate Sustainability}

The term "sustainability" has different meanings to different constituencies (Atiq, 2014; Camilleri, 2013, Pirhadi \& Feyzbakhsh, 2021). Some authors (Camilleri, 2017; Dumphy, 2014; Lozano, 2013; Visser, 2011; Montiel, 2008; Salzmann et al., 2005; and Dyllick \& Hockerts, 2002) viewed sustainability as responsible behaviors of Business Corporation. The above-mentioned authors have recognized the need that corporations should have social and environmental responsibility together with their economic interests. They further maintained that business, social and ecological interests of corporations are interconnected to each other. Authors like Van Marrewijk (2003) and Salzmann et al. (2005) attempted to structure business, social and ecological interests of corporate sustainability into value systems which can enhance financial performance. Similarly, Porter and Kramer (2002 \& 2011) maintain that "corporate sustainability can reduce the downside operational risk when it comprises relevant performance measures that are intended to increase eco-efficiency, health and safety issues".

\section{Sustainable Corporate Entrepreneurship as an Emerging Concept}

Sustainable entrepreneurship can be viewed as the process of considering opportunity driven approach that intend to fulfil unmet/less addressed socio-environmental needs to create simultaneous value for business and society. Entrepreneurship becomes sustainable when it creates three kinds of benefits: (i) business, (ii) social and (iii) environmental (Miles et al., 2009). Firstly, business benefits are created from sustainable practices when it improves financial performance viz., profitability, productivity and market share of corporation. Secondly, social benefits are created when sustainable practices improve employee job satisfaction, customer loyalty, attitudes of local community, brand image for environmental involvement and favorable policy formulation by government. The above mentioned latent benefits convert into the monetary value if entrepreneurs consider those in the long run and manage their day-to-day operations in an ethical, transparent and accountable manner. Finally, sustainable practices create environmental benefits if such practices improve stakeholders' environmental perceptions. The socio-economic-environmental responsibilities of business corporations are in essence supported by important prior researches (e.g., Husted et al., 2012; Bhattacharya et al., 2011; Landrum 2007; Anderson \& Markides, 2007; Falck \& Heblich 2007; Wheeler et al., 2003 \& 2005; Elkington 1998; Waddock and Graves 1997; and Pava and Krausz 1996).

It is worthwhile to note that many of the above-mentioned propositions have recognized that economic progress and societal progress are mutually dependent as is emphasized by CSV notion. However, the above-mentioned propositions did not observe simultaneous social and business value as is argued by CSV that implies 'creating economic value' by addressing unmet needs and challenges of a particular society through innovating core products/services of corporation rather than considering societal issues as a side line business as philanthropy does. Hence, how to boost competitiveness and economic value of corporation by integrating sustainability into core business activities is a crucial question. The answer to this question lies on the process through which entrepreneurs initiate innovations and ethics in their existing core business and new business solutions (Weidinger et al., 2014).

The CSV proposition however, contradicts with the traditional corporate social responsibility proposition. The traditional thoughts viewed CSR as the "businessmen's decisions and actions that go beyond a firm's direct economic and technical interest" (Davis, 1960, p.70). Similarly, McGuire (1963) and Davis \& Blomstrom (1966) viewed that 
"corporate social responsibilities extend beyond their economic and legal obligations". Later on, Fitch (1976) observed that "CSR is the serious attempt of corporations to solve societal problems that created by them". Thereafter, Carroll (1979) added "ethical and discretionary expectations" with the "economic and legal obligations" of existing definition of CSR. In his 1991 research work Carroll revised his CSR definition and added philanthropic functions into the previous four parts.

Clarkson (1995) observed that due to adopt CSR initiatives, corporations get strategic ideas to fulfill stakeholders' interests however; the author believed that CSR strategy confined business corporations to address only 'a selection of problems faced by societies'. While most scholars agreed that CSR propositions benefit the society, they disagreed on shareholders' 'direct benefits' (Porter \& Kramer, 2006 \& 2011; Mcwilliams et al., 2006; Hart \& Milisten, 2003). The reasons why scholars disagreed "about the efficacy of this kind of social responsibility" are (i) CSR effort is taken by corporations due to external pressure (Porter and Kramer 2011; Broomhill, 2007; Bendell, 2004) and (ii) CSR effort is isolated from corporate strategy (Porter and Kramer 2011). Previous studies have investigated the relationship between Corporate Social Performance and Corporate Financial Performance. Researchers such as Orlitzky et al., (2003); Preston \& O'bannon, (1997); Bruke \& Logsdon, (1996) and Waddock \& Graves, (1997) have established that CSR initiatives of corporations help improve their financial outcome. Other researchers such as Margolis \& Walsh, (2001); Mcwilliams \& Siegel, (2000); and Griffin \& Mahon (1997) have disproved the abovementioned relations. Corporate CSR initiatives are sometimes criticized as nothing but "blue washing, 'green washing or public relations campaign" (in Waddock, 2008).

From reviewing relevant academic literature in the field Camilleri (2017) have found that "today's corporations are strategically reorienting their business toward corporate sustainability and corporate responsibility and focusing on their stakeholders' needs at the same time". The strategic view of corporate sustainability is commonly known as CSV. Although Aakhus \& Bzdak, (2012) agreed on the fact that CSV strategy has popularity and acceptability in the corporate circles, the authors disagreed about the pure contribution of this strategy. Similarly, Crane et al., 2014 mentioned several shortcomings of CSV approach: "it is unoriginal, it ignores the tensions intrinsic to the responsible business activity, it is naive about regulatory compliance, and it is based on a shallow conception of the corporation's role in society". Dembek et al., 2(015) maintained that the CSV proposition is vague because the author finds gap in its definition and operation process. Similarly, Beschorner, 2013 noted that 'Porter's and Kramer's economic arguments is too normatively thin to do the important work of reconnecting businesses with society and as a result, prospects for a genuine reinvention of capitalism lie elsewhere".

Despite having criticisms in the academic circles, CSV approach is better than that of the CSR approach because in CSV social activities are directly linked to corporate goals. Moreover, CSV approach considers corporation will carry out societal responsibility internally rather than pressurized from external sources. Porter and Kramer (2011) clarified that "Shared value is not about personal values, nor about sharing the value already created by firms, instead, shared value is about expanding the total pool of economic and social value". Hence, earning fair profit from business venture that address social problem is justified. Again, philanthropy can create shared value (social and business value) if it is done aligning to the corporate strategy (Porter and Kramer, 2006). However, like CSR, CSV also relies for its efficacy on addressing social needs, complying with regulatory requirements, conforming ethical standards, and reducing noxiousness of corporate actions (Porter and Kramer, 2011). 


\section{Framework for Analyzing CSV}

Porter and Kramer (2011) have proposed that a corporation can create shared value through: (i) 'innovating products and markets', (2) 'reconfiguring value chain' to enhance productivity growth, and (3) 'enabling local clusters' that are supportive to the business. A detailed account of the above-mentioned approaches is given below as their characteristics are central to develop decision rules to recognize banking products or services that can be characterized as SCE.

\section{Approach 1: Innovating products and markets}

To mean 'Innovating products and markets,' Porter and Kramer (2011) pointed corporations to satisfy unmet needs of a particular society in which the business operates. The authors have made it clear that if corporations want to construct business and social value concurrently, they must be innovative in offering their core products or services targeting the poor and disadvantaged segments of society. Thus, banking corporations in a developing country can innovate their products and services considering the following social problems: inadequate banking access to majority of low income people, inadequate bank finances to agriculture, SME, and rural customers, scarcity of rural branches, lack of education in rural customers and small business persons, lack of self employment opportunities; environmental footprint due to financing environment polluting industries; and the like. Banks have greater options to generate shared value by considering the above mentioned social problems and identifying many others like these.

In their subsequent researches, the authors have also clarified the measurement indicators through which shared value can be measured and upscale. The indicators for measuring business value include "improved profitability, productivity, market share, quality, goodwill, and brand image, reduced operating costs and resources use". Whereas, indicators for measuring social value include but are not limited to "improved selfemployment opportunities, improved access to banking of low income group, improved beneficiary income, improved regulatory compliance, improved government income in terms of taxes, improved customer and employee learning, improved responsible and ethical practices, less environmental footprint and social disorder" (Porter and Kramer 2011).

\section{Approach 2: Reconfiguring value chain}

Porter \& Kramer (2011) have clarified how "social problems create economic costs in the firm's value chain" and therefore suggested corporations to scrutinize factors that might affect the value chain activities. The aforementioned authors particularly suggested corporations to scrutinize their "energy and resources use, logistics, distribution, health and safety, working conditions, equal treatment in the workplace and employee productivity". Banking corporations in a developing country have a great potential to reconfigure their interrelated processes and activities in order to boost productivity growth. Some of the ways are mentioned here: (i) embarking in fully automation and online banking (ii) ensuring inhouse environment friendly practices by avoiding paper use (customer notification via email/SMS instead of printing), face-to-face meeting, and (iii) using alternative low cost power such as solar energy. This interrelated process reconfiguration will not only save corporate money because of low paper, energy and transport cost but will also minimize ecological footprint and noxiousness of banking activities. Simultaneously, these practices will save customer costs and physical annoyance of getting banking services in a long queue and will improve service quality, convenience, and reliably thus social value will be created. 


\section{Approach 3: Enabling local clusters}

Cluster means "geographic concentration of firms, related businesses, suppliers, service providers, and logistical infrastructure in a particular field" Porter and Kramer (2011). Improving local clusters is a must for the success of business corporations because it helps them to improve corporate own "productivity, innovation, competitiveness and growth". Banking corporations in a developing country have a great potential to enable their local clusters. For example, if a bank wishes to engage in cluster based financing for a food company, it must look for farmers who produce agro-products, suppliers who supply agroproducts to the company, and retailers who sell the agro-based food to their outlet. It must also look for any educational/training institutes that are educating farmers about their crops to grow-up in proper condition.

\section{Methodology}

The study has been conducted on publicly traded commercial banks in a developing country context like Bangladesh. It has randomly selected 50 percent of the commercial banks out of 30 Dhaka Stock Exchange Limited (DSE) listed commercial banks (see for list shown in Appendix Table-1).

The research has used both quantitative and qualitative information collected from secondary sources. First of all, it was developed a set of decision rules (3.1)) to recognize banking products or services that can be characterized as SCE. The decision rules have been set by reviewing the literature in the domain of SCE, CSR, and CSV. Thereafter, it employed 'content analysis'-a technique for gathering and analyzing the meaning, ideas, themes, or message of text" (Neuman and Kreuger, 2006 in Bissoon, 2018) to critically evaluate information regarding SCE provided in the corporate annual reports (Islam \& Hossain, 2019, 2018 \& 2017; Rizk et al., 2008; Deegan \& Gordon, 1996). It has conducted "content analyses in light of the decision rules developed (shown in 3.1 below). It is the fact that every corporation that have been selected for conducting this research do publish their corporate information in several means other than annual report such as website, newsletter, research report, and media. The present study relied on corporate annual report on the ground that it is "a statutory document and can be considered more reliable than other means of disclosure" (Gray et al., 1995; Neu et al. 1998). The study has scrutinized corporate annual reports for a five-year period started from 2013 to 2017. The objective was to show if the SCE performances of the selected corporations were persistent over the period.

\section{Decision Rules for Analyzing SCE in the Banking Corporations}

The following decision rules apply for the banking corporations to analyze their SCE:

1. the product/service offerings should be opportunity driven and that should benefit commonly considered low income people

2. the initiative should create simultaneous values or in other words it will not create value for only one group

3. the initiatives must come from core strategy

4. here profit from social purpose is justified

5. investment will be regarded as environment friendly if it is done to firms that have Effluent Treatment Plant (ETP) in place, or to purchase ETP, or investment to those firms/endeavor that is engaged in environment protection

6. disclosure of information in annual audited report will be regarded as true 


\section{Research Findings and Discussions}

SCE Initiatives at a Glance

Table-1 below demonstrates SCE initiatives that have been taken by commercial banks in line with three core dimensions of CSV notion developed by Porter, ME and Kramer, MR (2011). In area-1, 'innovating products and markets', it has found that the commercial banks have innovated their products and services focusing on markets that still remain less addressed (viz., agriculture, SMEs, ventures of women entrepreneurs, firms that are promoting environment friendly products/initiatives, school going children, and rural unbanked people among others). Corporate investment in those markets are improving access to banking for the unbanked people, improving client convenience, improving regional economic growth, creating self-employment in rural areas, increasing revenues and profits, reducing public mistrust on banking activities and reducing environmental footprint because of digital financial inclusion of rural people. By investing into these ever-neglected markets, banking corporations are creating social value. At the same time, banking corporations are also earning incremental revenue and profits from those markets thus creating shard value.

In area-2, 'reconfiguring value chain', the study has identified some crucial efforts (shows in Table-1 below) that have been implementing by commercial banks. The configuration of interrelated series of processes seemed to improve productivity growth of the banking corporations because it genuinely helped them to operate their business functions efficiently than ever before.

And in area-3, 'enabling supportive industry clusters', the study has observed that the commercial banks have also presence in the cluster-based financing. This process is contributing to employment generation, productivity growth and upgrading lower segment of the society. In this area, it is also found that the corporation that is strong in technological resources such as ATM networks is sharing with competitors in the industry. This sharing opportunity is reducing fixed asset expenses for other corporations. 


\author{
Table-1: Summary of SCE along Porter and Kramer (2011) CSV Notion \\ Areas of Effort \\ Area-1: Innovating products and markets \\ - Introducing need-based finance schemes for SMEs \\ - Micro finance to ever neglected Agricultural sector \\ - Introducing credit facilities specially for women entrepreneurs \\ - Banking services through cell phone/MFS \\ - Branch less banking in the remote areas employing agent \\ - School Banking targeting school children \\ - Fast Track Services \\ - Environment friendly investment ( see details in 4.5.4) \\ - Creating climate risk fund and introducing environmental risk \\ management policies and practices \\ Outcomes of the efforts \\ - Improving access to banking for the \\ unbanked people \\ - Improving client convenience \\ - Improving regional economic \\ growth \\ - Increasing revenue and profits \\ - Creating self employment in rural \\ areas \\ - Digital financial inclusion reducing \\ environmental footprint and mistrust \\ about banking activities
}

- Corporate Social Responsibility (major areas include: education, health care, sports \& cultural activities, relief for natural disasters)

Area-2: Reconfiguring value chain

Following crucial efforts have been taken to improve productivity growth:

- Digital transactions and communications

- Expansion of ATM and POS services

- Expansion of mobile banking agent networks and services

- Evaluation of environmental risk before granting loan

- Developing supportive industry clusters

- Special emphasis to finance ventures of women entrepreneurs

- Strong surveillance and monitoring

- Inter-bank gross settlement

- Employee training focusing on efficient use of resources (paper, electricity, gas, fuel etc)

- In-house environment friendly practices

- Special training on environment related issues (viz., project risk assessment, in-house practices, marketing)

Area-3: Enabling supportive industry clusters

- financing associated clusters in SME sector supportive to the industry

- sharing own ATM network with industry members

- Proper management of these processes are escalating productivity growth and reducing operational risks (except the internet based banking that are increasing security risks)

- Improving ethical banking practices due to widespread online services

- This process is contributing to employment generation, productivity growth and upgrading lower segment

- Sharing opportunities are reducing

fixed asset expenses of other

corporations

Source: Content analysis from 2013-17 corporate annual reports of selected banks

\section{SCE to SME Sector}

SME sector is considered to be the thirst sector of any developing economy and therefore this sector provide opportunities for banking corporation to generate shared value. The study has found that commercial banks have taken several effective actions to facilitate this market. Some the actions include: creating separate SME division, selecting SME prone areas, opening specialized SME branches in those areas, introducing different need-based finance schemes for SMEs, adopting cluster-based approach for financing to SMEs and participating and/or sponsoring in meetings, seminars, symposiums, and fairs concerning SME sector development.

Despite the above-mentioned facts, quantitative analysis about finance in the SMEs demonstrates disappointing information. While the investment amount in the SME sector 
has been increasing year after year, it is not increasing proportionately with their general investment. Table-2 (shown in Appendix) discloses that SME investment of the entire banks had increased in absolute terms (compared with the previous year' investment). However, the SME investment decreased for majority (57.14\%) of the banks in relative terms (compared with general investment of banks). For the banks, such as DBL, BRAC, JBL, MBL, SBL and NBL, however, SME investment had increased in relative terms. In relative terms, SME investment had increased by $12.56 \%$ in BRAC subsequently $12.50 \%$ in NBL, $8.66 \%$ in DBL, 6.94\% in MBL, and a negligible 0.06\% in SBL. However, in relative terms, SME investment had decreased sharply by $24.95 \%$ in UBL subsequently $12.42 \%$ in UCB, 9.35\% in DBBL, $8.19 \%$ in EXIM, $4.02 \%$ in ABBL, 3.96\% in IFIC, $1.85 \%$ in EBL and slightly $0.38 \%$ in IBBL. Thus, the findings reveal that SME investment (the most noteworthy SCE initiative) in relation to general investment decreased in majority of the banks even if it increased year after year for all banks. Thus, to create upscale shared value, banking corporations are suggested to increase their SME investment relative to their total general investment.

The study also reveals that each of the banks has reported that they have adopted cluster-based approach for financing to SMEs but only 21.42 percent of them have reported their financing scenarios, which is negligible. Of the banks that have reported cluster-based financing approach, IBBL comes first. It has disbursed 12,600 million BDT among $40 \mathrm{SME}$ clusters, followed by DBL (39.62 million BDT in a single SME cluster), and BRAC (20 million BDT in a single SME cluster).

\section{SCE toward Women Entrepreneurs}

Women entrepreneurs in a developing country like Bangladesh constitute another market destination of banking corporations as it is the fact that half of the population is women. This market contains huge potential for socio-economic development and for creating shared value. However, this market still remains unexplored. The players of the market are facing lots of constrain to make their business venture successful. Some of the key constraints are "Lack of education, family values, and inadequate financial facilities" (Islam, 2018). In line with central bank's guidelines, the entire banks have opened 'women entrepreneur dedicated desk' to deal with the affairs of women entrepreneurs. However, a negligible percentage $(35.71 \%)$ of the banks has reported the amount of fund they disbursed among women entrepreneurs. Of the banks that have reported women entrepreneurs' loan, IBBL comes first. At the end of 2017, IBBL had disbursed 8490 million BDT among 3200 women entrepreneurs, followed by SBL (1533.40 million BDT among 189 women entrepreneurs), IFICBL (771 million BDT among 352 women entrepreneurs), DBL (413.85 million BDT among 81 women entrepreneurs), and EXBL (379.78 million BDT among 273 women entrepreneurs).

\section{SCE toward Agricultural Sector}

Table-3 (shown in Appendix) delineates that total agricultural disbursement of commercial banks had increased both in absolute terms $((100 \%)$ and in relative terms $(57.14 \%)$. Bank finances to the agricultural sector however slightly decreased in DBL $(0.11 \%)$, followed by MBL $(0.38 \%)$, JBL (0.40\%), EXIM (0.52\%), IBBL (0.86\%), and UCB (1.62\%). While the above statistics depict that commercial banks have presence in the agricultural sector development, the exposure in this sector however is insignificant compared to market demand. Every year BB sets target for commercial banks under its jurisdiction to have at least 2 percent exposure of their total general investment to the agricultural sector. If any 
bank fails to do so, BB set aside their unused fund to a block account and creates impediments of those banks in getting approval of different issues from BB. Therefore, it is evident that most of the banks are looking for shortcut way to avoid such unpleasant situation. The search for shortcut way is obviously making the commercial banks dependent on Non-Government Organizations (NGOs) to disburse micro-credit. This dependency on NGOs again pushing farmers and rural agro-based businessmen to pay extra cost because these organizations can charge accumulated interest up to 27 percent as approved by micro finance regulatory authority. It is desired that in this case banks will devise ways to directly disburse the fund to the target group. Off course, the entire banks reported that they do disburse agricultural loan through their own branch in addition to NGO linkage. Moreover, 66.67 percent of them reported that they do disburse agricultural loan less than that of the target set by the BB. The rate of failure to disburse targeted amount was more pronounced in SBL than others banks.

\section{Environment Friendly Banking}

The environment friendly practices of the commercial banks reflect on the following: inhouse code of conduct, environmental risk rating before investment, sustainable finance to mitigate climate change risks, mobile financial services for the unbanked and loans to sustainable industries. The above-mentioned SCE initiatives are clarified in the sub-headings 4.5.1 to 4.5.5 below:

\section{Internal Green Practices}

The study observed that as part of their internal code of conduct, the entire banks have reported the following initiatives:

- Electronic inter-bank fund transfer, electronic clearing system, online banking services, and short message service (SMS) notification in cell phone etc. have remarkably reduced paper based transaction.

- In-house HRM, CIB and MIS software for reducing manual paperwork.

- Collection of utility bills for service companies and maintenance of report through online system.

- Installing energy efficient electronic equipments

- Video conferencing and IP telephony systems for internal communication

- Expansion of ATM network

However, 13.33 percent of the banks have reported their annual paper, power, and fuel costs have been reduced due to the above-mentioned initiatives. Others did not report that kind of information thus could not be known. Each of the banks has reported at least one of their Branches and ATM booth is using solar energy to reduce electric power and they have policies to implement the plan gradually. Remarkably, the entire banks had arranged at least one training session for their employees on 'environment friendly banking'.

\section{Sustainable Finance Unit}

The entire banks have reported that they have "Sustainable Finance Unit" as well as "Sustainable Finance Committee" and these units are working under the guidelines set by the central bank. However, 40 percent of the banks have reported that they have allocated fund to mitigate climate change risks. It is noted here that bank can use the fund at low rate investment to the disaster-prone community or donate as part of their CSR activity. 


\section{Environmental Risk Rating}

Each of the banks has reported that they have rated projects for environmental risk as high, moderate and low and invested in the low and moderate risky projects and avoided high risky projects.

\section{Environment Friendly (Green) Loan Scenarios}

The banking corporations are in effect investing in businesses that are conducting environment friendly operations. The banks themselves use the term 'direct green investment' and 'indirect green investment' to describe their environment friendly investment. The banks termed it 'direct green investment' when they invest to businesses that produce/market green products, set up green plants, want to purchase eco-friendly energy and the like. On the other hand, the banks termed it 'indirect green investment' when they grant working capital to plants/industry that have effluent treatment plant in place). Table-4 (shown in Appendix) demonstrates that $80 \%$ of the banking corporations have exposures to both direct and indirect green investment. Appendix Table-4 also demonstrates that total (direct and indirect combined) green investment had remained incessant during the study period for IBBL, EXIM, MBL, IFIC, SBL and NBL. For these banks, it was increased from 2013 to 2017 by $2.19,3.45,2.55,4.65,3279$ and 3.60 times respectively. The total green investment for these banks again was increased over general investment by $2.69,9.45$, $0.04,2.43,6.01$ and 0.82 times over the period of review. However, the rates were negative compared with general investment for UCB, EBL, JBL, and DBBL though these banks were shown yearly positive growth for such investment.

\section{Mobile Financial Services (MFS)}

Another SCE initiative of commercial banks is MFS, which means providing banking services for the unbanked people using cell phone account. The central bank of Bangladesh has provided license to "a total of 28 banks, of them 20 banks have started operation as of July 2016". Up to 2015, these banks have been able to register a total of 28.64 million customer accounts. During the same time a total of 0.53 million agents were registered to provide the service to the customers and average transactions recorded BDT 4.32 billion per day (Islam and Hossain, 2018).

The money transfer service (cash out, merchant payment, e-commerce) is performed on the basis of commission which is regarded as business value for banks. Simultaneously, the MFS is creating social value in several ways: (i) providing unbanked people banking services at low cost, (ii) creating self-employment opportunities for agents, (iii) facilitating doorstep remittance send by the expatriates who were previously depended on illegal traders, and (iv) reducing environment footprint as the digital and doorstep transaction facilities disallowing people going long distance boarding on mechanized vehicles.

Although entire banking corporations have launched digital financial inclusion through MFS, bKash of BRAC Bank, Rocket of Dutch-Bangla Bank, Mcash of Islamic Bank and Ucash of United Commercial Bank perform 90 percent of total transactions.

It is worthwhile to mention that EPS (see Appendix Table-5) as well as contribution (i.e., tax, value added tax, levies) to National Exchequer (see Appendix Table-6) had an increasing trend and remained incessant over the study periods for those commercial banks that have been invested in SCE products (SME, Agriculture, MFS, direct and indirect credit facilities to the environment friendly organizations). Moreover, rate of Non Performing Loan 
(NPL) was almost zero in those investments particularly in micro-finance in agricultural sector.

The overall findings suggest that the commercial banks have been engaged in SCE which have been creating shared value in line with the areas of CSV concept but mostly through their product and service innovation (area-1) and value chain reconfiguration (area-2). In essence, few banks are creating shared value through enabling local cluster. Thus, CSV notion can partially be applied to explain the current SCE practices of publicly traded commercial banks in the context of developing country like Bangladesh.

\section{Policy Recommendations}

To create upscale 'shared value', banking corporation should:

1. increase investment to SCE initiatives in relative terms (in relation to their general investment),

2. consider SCE initiatives as core of strategic choices but not as a side line like CSR does,

3. strictly monitor environmental footprint from investment decisions,

4. go beyond merely following central bank's guidelines to include financially distressed,

5. benchmark company activities that are sustainable and implement by their own discretion,

6. stay behind eye washing activities. Being the environment friendly should be the passion but not be the fashion,

7. increase rural operations/visibility not through expensive branch operations but through digital financial inclusion (i.e., MFS, agent banking etc.). In this case banks must address money laundering and digital security issues properly,

8. invest to educate rural customers and to prepare concrete database of financially distressed (women entrepreneurs, rural and urban poor, firms of local agro-business and SMEs),

9. ensure loan disbursement to those who are financially distressed (women entrepreneurs, rural and urban poor, firms of local agro-business and SMEs) rather than merely pursuing the solvent, and

10. avoid short term profit mentality to grasp the real opportunities of sustainability.

\section{Conclusion}

The paper was aimed to explain if CSV notion can be used as a plausible explanation of current SCE practices of publicly traded commercial banks in the context of developing country. The findings suggest that EPS as well as contribution to National Exchequer had an increasing trend and remained incessant over the study periods for those banks that have been invested in SCE products (viz., SMEs, Agriculture, Environment protection, and MFS). Moreover, for these SCE initiatives, greater number of unbanked people (who had no access to banking for long due to their token transaction) has come under the commercial banking services. Moreover, rate of Non-Performing Loan (NPL) was almost zero in those investments particularly in micro-finance in agricultural sector. This finding can substantiate CSV notion of Porter and Kramer (2011) in that the SCE practices has been creating social value and business value simultaneously. However, the empirical finding also suggests that the SCE performances have been increasing in absolute terms (over the year) in most of the cases but not in relative terms (over general investment). The findings thus partly support CSV notion to explain current practices of SCE. 


\section{Limitations and Suggestions for Further Study}

The study possesses several shortcomings: (i) the findings may not represent the actual motives of the board of directors and managers if the annual reports used provide any overwhelming data; (ii) the study has no reflection of stakeholders' (viz., customers, stockholders) perception on the effectiveness SCE; (iii) the current study has conducted on commercial banks only thus may not represent the whole financial sector (as there are bank and non-bank financial institutions in place). The above-mentioned limitations open up the avenues for future research. Future studies can contribute to the existing knowledge by exploring how and to what extent stakeholders of financial sectors perceive effectiveness of SCE initiatives.

\section{References}

Aakhus, M., \& Bzdak, M. (2012). Revisiting the Role of "Shared Value" in the BusinessSociety Relationship. Business and Professional Ethics Journal 31(2), 231-46. doi: 10.5840/bpej201231211

Agarwal S. K. (2008). Corporate Social Responsibility in India. New Delhi: SAGE.

Amit, R., Glosten, L., \& Muller, E. (1993). Challenges to Theory Development in Entrepreneurship Research. Journal of Management Studies, 30(5), 815-834.

Anderson J., \& Markides, C. (2007). Strategic Innovation at the Base of the Pyramid. MIT Sloan Manag Rev 49(1):83-88. http://sloanreview.mit.edu/wpcontent/uploads/saleable-pdfs/49116.pdf (accessed June 18, 2020).

Atiq, M. (2014). "Sustainable Corporate Entrepreneurship: Insights from Pakistan." PhD diss., University of Southampton. http://eprints.soton.ac.uk/365500/1 hasCoversheetVersion/Atiq,\%20Muhammad\%20fi n\% 20thesis.pdf (accessed August 29, 2016).

Baltazar A.P.P.D. (2011). Corporate Social Responsibility from an Employees' Perspective: Contributes for Understanding Job Attitudes. PhD Diss., Department of Social and Organizational Psychology, ISCTE-IUL, 11. https://www.researchgate.net/publication/235428586_Corporate_social_responsibility _from_an_employees'_perspective_Contributes_for_understanding_job_attitudes (accessed August 29, 2016).

Bendell, J. (June 2004). Barricades and Boardrooms: A Contemporary History of the Corporate Accountability Movement. UNRISD Technology, Business and Society Programme Paper, no. 13: 1-63.

Beschorner, T. (2013). Creating Shared Value: The One-Trick Pony Approach. Business Ethics Journal Review, 106-12. doi: 10.12747/bejr 2013.01.17

Bhattacharya, C. B., Sen, S., \& Korschun, D. (2011). Leveraging corporate responsibility: The stakeholder route to maximizing business and social value. Cambridge, U.K.: Cambridge University Press.

Bissoon O. (2018). Corporate social responsibility in Mauritius: An Analysis of Annual Reports of Multinational Hotel Groups. Asian Journal of Sustainability and Social Responsibility 3(2),1-19. https://doi.org/10.1186/s41180-017-0017-4

Broomhill R. (2007). Corporate Social Responsibility: Key Issues and Debates. Dunstan $\begin{array}{llll}\text { Paper-Don } & \text { Dunstan } & \text { Foundation, } & \text { no. }\end{array}$ http://www.dunstan.org.au/resources/publications/Dunstan_Papers_No_1_2007.pdf (accessed April 30, 2015).

Burke, L., \& Logsdon, J. M. (1996). How corporate social responsibility pays off. Long Range Planning, 29(4), 495-502. doi:10.1016/0024-6301(96)00041-6 
Camilleri, M. (2013). Advancing the Sustainable Tourism Agenda Through Strategic CSR Perspectives. Tourism Planning \& Development, 11(1), $42-56$. doi:10.1080/21568316.2013.839470

Camilleri, M. A. (2017). Corporate Sustainability, Social Responsibility and Environmental Management: An Introduction to Theory and Practice with Case Studies. Cham, Switzerland: Springer Nature, an imprint of Springer International Publishing AG.

Carroll, A. B. (1979). A Three-Dimensional Conceptual Model of Corporate Performance. The Academy of Management Review, 4(4), 497-505. doi:10.2307/257850

Carroll, A. B. (1991). The pyramid of corporate social responsibility: Toward the moral management of organizational stakeholders. Business Horizons, 34(4), 39-48. doi:10.1016/0007-6813(91)90005-g

Clarkson, M. E. (1995). A Stakeholder Framework for Analyzing and Evaluating Corporate Social Performance. Academy of Management Review, 20(1), 92-117. doi:10.5465/amr.1995.9503271994

Crane, A., Palazzo, G., Spence, L. J., \& Matten, D. (2014). Contesting the Value of "Creating Shared Value". California Management Review, 56(2), 130-153. doi:10.1525/cmr.2014.56.2.130

Davis, K. (1960). Can Business Afford to Ignore Social Responsibilities? California Management Review, 2(3), 70-76. doi:10.2307/41166246

Davis, K., Blomstrom, R. L. (1966). Business and its environment. New York: McGrawHill.

Deegan, C., \& Gordon, B. (1996). A Study of the Environmental Disclosure Practices of Australian Corporations. Accounting and Business Research, 26(3), 187-199. doi:10.1080/00014788.1996.9729510

Dembek, K., Singh, P., \& Bhakoo, V. (2015). Literature Review of Shared Value: A Theoretical Concept or a Management Buzzword? Journal of Business Ethics, 137(2), 231-267. doi:10.1007/s10551-015-2554-Z

Dunphy, D. C. (2014). Organizational change for corporate sustainability: A guide for leaders and change agents of the future. London: Routledge.

Dyllick, T., \& Hockerts, K. (2002). Beyond the business case for corporate sustainability. Business Strategy and the Environment, 11(2), 130-141. doi:10.1002/bse.323

Eckhardt, J. (2003). Opportunities and Entrepreneurship. Journal of Management, 29(3), 333-349. doi:10.1016/s0149-2063(02)00225-8

Elkington, J. (1998). Partnerships fromcannibals with forks: The triple bottom line of 21stcentury business. Environmental Quality Management, 8(1), 37-51. doi:10.1002/tqem.3310080106

Falck, O., \& Heblich, S. (2007). Corporate social responsibility: Doing well by doing good. Business Horizons, 50(3), 247-254. doi:10.1016/j.bushor.2006.12.002

Fitch, H. G. (1976). Achieving Corporate Social Responsibility. Academy of Management Review, 1(1), 38-46. doi:10.5465/amr.1976.4408754

Gray, R., Kouhy, R., \& Lavers, S. (1995). Corporate social and environmental reporting. Accounting, Auditing \& Accountability Journal, 8(2), 47-77. doi:10.1108/09513579510146996

Griffin, J. J., \& Mahon, J. F. (1997). The Corporate Social Performance and Corporate Financial Performance Debate. Business \& Society, 36(1), 5-31. doi:10.1177/000765039703600102

Hart, S. L., \& Milstein, M. B. (2003). Creating sustainable value. Academy of Management Perspectives, 17(2), 56-67. doi:10.5465/ame.2003.10025194 
Husted, B. W., Allen, D. B., \& Kock, N. (2012). Value Creation Through Social Strategy. Business \& Society, 54(2), 147-186. doi:10.1177/0007650312439187

Islam, M. R. (2017). Creating Shared Value at Dutch-Bangla Bank Limited in Bangladesh. American Journal of Theoretical and Applied Business, 3(3), 54. doi:10.11648/j.ajtab.20170303.13

Islam, M. R., \& Hossain, S. Z. (2019). Conceptual mapping of shared value creation by the private commercial banks in Bangladesh. Asian Journal of Sustainability and Social Responsibility, 4(3). doi:10.1186/s41180-019-0024-8

Islam, M.R. (2018). Banking on shared value: A study on private commercial banks in Bangladesh. PhD diss., Institute of Bangladesh Studies, University of Rajshahi.

Islam, M.R., Hossain, S.Z. (2018). Creating shared value through mobile financial services in Bangladesh. International Journal of Development and Sustainability 7(2): 620-638. https://isdsnet.com/ijds-v7n2-14.pdf (Accessed 5 Oct 2018).

Islam, MR (2021). Sustainable Entrepreneurship in the Light Engineering Industries: A Developing Country Perspective. Journal of Nepalese Business Studies 14(1), (accepted for publication).

Jenkins, R. (2005). Globalization, Corporate Social Responsibility and poverty. International Affairs, 81(3), 525-540. doi:10.1111/j.1468-2346.2005.00467.x

Landrum, N. E. (2007). Advancing the "base of the pyramid" debate. Strategic Management Review 1(1), 1-12.

Lozano, R. (2013). A Holistic Perspective on Corporate Sustainability Drivers. Corporate Social Responsibility and Environmental Management, 22(1), 32-44. doi:10.1002/csr.1325

Margolis, J.D., Walsh, J.P. (2001). People and profits? The search for a link between a firm's social performance and financial performance. Mahwah: Lawrence Erlbaum Publishers.

McGuire, J.W. (1963). Business and society. New York: McGraw-Hill.

Mcwilliams, A., Siegel, D.S. (2000). Corporate social responsibility and financial performance: correlation or misspecification? Strategic Management Journal 21(5):603-609. https://doi.org/10.1002/(sici)1097-0266(200005)21:53.3.co;2-v

Mcwilliams, A., Siegel, D.S., \& Wright, P.M. (2006). Corporate social responsibility: strategic implications. J Manag Stud 43(1):1-18. https://doi.org/10.1111/j.14676486.2006.00580.x

Miles, M.P., Munilla, L.S. \& Darroch, J. (2009). Sustainable corporate entrepreneurship. Int Entrep Manag J 5, 65-76. https://doi.org/10.1007/s11365-008-0074-3

Montiel, I. (2008). Corporate Social Responsibility and Corporate Sustainability. Organization \& Environment, 21(3), 245-269. doi:10.1177/1086026608321329

Neu, D., Warsame, H., \& Pedwell, K. (1998). Managing Public Impressions: Environmental Disclosures in Annual Reports. Accounting, Organizations and Society, 23(3), 265-282. doi:10.1016/s0361-3682(97)00008-1

Neuman, W. L., \& Kreuger, L. (2006). Social work research methods: Qualitative and quantitative approaches. Boston: Allyn and Bacon.

Orlitzky, M., Schmidt, F. L., \& Rynes, S. L. (2003). Corporate Social and Financial Performance: A Meta-Analysis. Organization Studies, 24(3), 403-441. doi:10.1177/0170840603024003910

Pava, M. L., \& Krausz, J. (1996). The association between corporate social-responsibility and financial performance: The paradox of social cost. Journal of Business Ethics, 15(3), 321-357. doi:10.1007/bf00382958 
Pirhadi, H., Feyzbakhsh, A. (2021). Corporate entrepreneurship, its antecedents, process, and consequences: A systematic review and suggestion for future research. $J$ Int Entrep 19, 196-222. https://doi.org/10.1007/s10843-021-00294-8

Porter, M. E., \& Kramer, M. R. (December 2002). The Competitive Advantage of Corporate Philanthropy. Harvard Business Review, 1-16.

Porter, M. E., \& Kramer, M. R. (December 2006). Strategy and Society: The Link between Competitive Advantage and Corporate Social Responsibility. Harvard Business Review 84(12): 78-92.

Porter, M. E., \& Kramer, M. R. (January-February 2011). The Big Idea: Creating Shared Value; How to Reinvent Capitalism - and Unleash a Wave of Innovation and Growth. Harvard Business Review 89(1/2): 62-77.

Preston, L. E., \& O'bannon, D. P. (1997). The Corporate Social-Financial Performance Relationship. Business \& Society, 36(4), 419-429. doi:10.1177/000765039703600406

Rizk, R., Dixon, R., \& Woodhead, A. (2008). Corporate social and environmental reporting: A survey of disclosure practices in Egypt. Social Responsibility Journal, 4(3), 306-323. doi:10.1108/17471110810892839

Salzmann, O., Ionescu-Somers, A., \& Steger, U. (2005). The Business Case for Corporate Sustainability: European Management Journal, 23(1), 27-36. doi:10.1016/j.emj.2004.12.007

Stokes, D., Wilson, N. \& Mador, M. (2010). Entrepreneurship. Andover: Cengage Learning. van Marrewijk, M. (2003). Concepts and Definitions of CSR and Corporate Sustainability: Between Agency and Communion. Journal of Business Ethics 44, 95-105. https://doi.org/10.1023/A:1023331212247

Visser, W. (2011). The age of responsibility: CSR 2.0 and the new DNA of business. John Wiley \& Sons, Chichester, west Sussex, U.K.

Waddock, S. (2008). Building a New Institutional Infrastructure for Corporate Responsibility. Academy of Management Perspectives, 22(3), 87-108. doi:10.5465/amp.2008.34587997

Weidinger, C., Fischler, F., \& Schmidpeter, R. (Eds.) (2014). Sustainable Entrepreneurship: Business Success through Sustainability. Berlin Heidelberg: Springer-Verlag.

Wheeler, D., Colbert, B., \& Freeman, R. E. (2003). Focusing on Value: Reconciling Corporate Social Responsibility, Sustainability and a Stakeholder Approach in a Network World. Journal of General Management, 28(3), 1-28. doi:10.1177/030630700302800301

Wheeler, D., Fabig, H., \& Boele, R. (2002). Paradoxes and dilemmas for stakeholder responsive firms in the extractive sector: Lessons from the case of Shell and the Ogoni. Journal of Business Ethics, 39(3), 297-318. doi:10.1023/a:1016542207069

Wheeler, D., McKague, K., Thomson, J., Davies, R., Medalye, J., \& Prada, M. (2005). Creating sustainable local enterprise networks. MIT Sloan Management Review 47(1), $33-40$. 


\section{Appendix}

Table 1: DSE \& CSE enlisted sample banks (with abbreviations and year of commencement)

\begin{tabular}{|l|l|l|l|}
\hline Item No. & Name of Selected Bank & Acronym & Year of Commencement \\
\hline 1. & Arab-Bangladesh Bank Ltd & ABBL & 1982 \\
\hline 2. & BRAC Bank Ltd & BRAC & 2001 \\
\hline 3. & Dhaka Bank Ltd & DBL & 1995 \\
\hline 4. & Dutch-Bangla Bank Ltd & DBBL & 1996 \\
\hline 5. & Eastern Bank Ltd & EBL & 1992 \\
\hline 6. & EXIM Bank Ltd & EXIM & 1999 \\
\hline 7. & IFIC Bank Ltd & IFIC & 1983 \\
\hline 8. & Islami Bank Bangladesh Ltd & IBBL & 1983 \\
\hline 9. & Jamuna Bank Ltd & JBL & 2001 \\
\hline 10. & Mercantile Bank Ltd & MBL & 1999 \\
\hline 11. & National Bank Ltd & NBL & 1983 \\
\hline 12. & Shahjalal Islami Bank Ltd & SIBL & 2001 \\
\hline 13. & Southeast Bank Ltd & SBL & 1995 \\
\hline 14. & United Commercial Bank Ltd & UCB & 1983 \\
\hline 15. & Uttara Bank Ltd & UBL & 1983 \\
\hline
\end{tabular}

Source: Website of Respective Banks 
Table-2: Growth in Small and Medium Enterprise (SME) Investments (Inv.)

\begin{tabular}{|c|c|c|c|c|c|c|c|}
\hline \multirow[t]{2}{*}{ Bank } & \multirow[t]{2}{*}{ Particular } & \multicolumn{5}{|c|}{ Yearly Disbursement (Million BDT) } & \multirow{2}{*}{$\begin{array}{l}\text { Continual } \\
\text { Growth } \\
\text { (Times) }\end{array}$} \\
\hline & & 2013 & 2014 & 2015 & 2016 & 2017 & \\
\hline \multirow[t]{3}{*}{$\mathrm{ABBL}$} & SME Inv. & 37380 & 42690 & 47510 & N/A & N/A & 1.27 \\
\hline & Total Inv. & 140,121 & 177,571 & 209,725 & 218,769 & 229,647 & 1.64 \\
\hline & SME Inv. to total Inv. (\%) & 26.68 & 24.04 & 22.65 & $\mathrm{~N} / \mathrm{A}$ & $\mathrm{N} / \mathrm{A}$ & $(4.02)$ \\
\hline \multirow[t]{3}{*}{ BRAC } & SME Inv. & 33,676 & 38,142 & 42,963 & 64,015 & 84,051 & 2.50 \\
\hline & Total Inv. & 117,111 & 121,941 & 147,434 & 175,841 & 203,431 & 1.74 \\
\hline & SME Inv. to total Inv. (\%) & 28.76 & 31.28 & 29.14 & 36.41 & 41.32 & 12.56 \\
\hline \multirow[t]{3}{*}{ DBBL } & SME Inv. & 23,434 & 22,478 & 22,719 & 23,720 & 26,268 & 1.12 \\
\hline & Total Inv. & 106,423 & 124,423 & 152,270 & 173,398 & 207,257 & 1.95 \\
\hline & SME Inv. to total Inv. (\%) & 22.02 & 18.07 & 14.92 & 13.68 & 12.67 & $(9.35)$ \\
\hline \multirow[t]{3}{*}{$\overline{\mathrm{DBL}}$} & SME Inv. & 8,703 & 10,725 & 12,227 & $21,509.00$ & $26,793.53$ & 3.08 \\
\hline & Total Inv. & 99,596 & 103,131 & 117,840 & 134,689 & 154,017 & 1.55 \\
\hline & SME Inv. to total Inv. (\%) & 8.74 & 10.40 & 10.38 & 15.97 & 17.40 & 8.66 \\
\hline \multirow[t]{3}{*}{ EBL } & SME Inv. & 16,640 & 18,279 & 19,518 & 22799 & 26,347 & 1.58 \\
\hline & Total Inv. & 102,910 & 118,291 & 130,226 & 152,084 & 184,027 & 1.79 \\
\hline & SME Inv. to total Inv. (\%) & 16.17 & 15.45 & 14.99 & 14.99 & 14.32 & $(1.85)$ \\
\hline \multirow[t]{3}{*}{ EXIM } & SME Inv. & $64,717.70$ & $84,825.90$ & $83,962.90$ & 89534.8 & 93412.6 & 1.44 \\
\hline & Total Inv. & 143,847 & 177,937 & 196,311 & 222,155 & 253,803 & 1.76 \\
\hline & SME Inv. to total Inv. (\%) & 44.99 & 47.67 & 42.77 & 40.30 & 36.81 & $(8.19)$ \\
\hline \multirow[t]{3}{*}{ IBBL } & SME Inv. & 173,660 & 201,127 & 229,950 & 257,070 & 303,430 & 1.75 \\
\hline & Total Inv. & 403,195 & 463,475 & 530,194 & 616,419 & 710,729 & 1.76 \\
\hline & SME Inv. to total Inv. (\%) & 43.07 & 43.40 & 43.37 & 41.70 & 42.69 & $(0.38)$ \\
\hline \multirow[t]{3}{*}{ IFIC } & SME Inv. & $16,794.60$ & $19,630.20$ & $20,271.80$ & 28,067 & 28,690 & 1.71 \\
\hline & Total Inv. & 84,110 & 102,282 & 123,269 & 137,118 & 179,264 & 2.13 \\
\hline & SME Inv. to total Inv. (\%) & 19.97 & 19.19 & 16.45 & 20.47 & 16.00 & (3.96) \\
\hline \multirow[t]{3}{*}{ JBL } & SME Inv. & 4048.8 & 6454.9 & 19295.9 & 14533.7 & $15,478.73$ & 3.82 \\
\hline & Total Inv. & 67,669 & 77,900 & 87,252 & 117,100 & 142,253 & 2.10 \\
\hline & SME Inv. to total Inv. (\%) & 5.98 & 8.29 & 22.12 & 12.41 & 10.88 & 4.90 \\
\hline \multirow[t]{3}{*}{ MBL } & SME Inv. & 7,250 & $9,068.66$ & $11,656.87$ & $14,540.00$ & 28671.28 & 3.95 \\
\hline & Total Inv. & $97,688.50$ & $117,060.03$ & $126,338.83$ & $150,912.52$ & $199,660.72$ & 2.04 \\
\hline & SME Inv. to total Inv. (\%) & 7.42 & 7.75 & 9.23 & 9.63 & 14.36 & 6.94 \\
\hline \multirow[t]{3}{*}{ NBL } & SME Inv. & $\mathrm{N} / \mathrm{A}$ & $28,428.00$ & $32,848.83$ & $61,729.69$ & $71,897.49$ & 2.53 \\
\hline & Total Inv. & 151,099 & 172,965 & 186,179 & 209,929 & 248,467 & 1.64 \\
\hline & SME Inv. to total Inv. (\%) & $\mathrm{N} / \mathrm{A}$ & 16.44 & 17.64 & 29.41 & 28.94 & 12.50 \\
\hline \multirow[t]{3}{*}{ SBL } & SME Inv. & 21494.05 & $28,946.70$ & $34,514.18$ & 40,000 & 37,491 & 1.74 \\
\hline & Total Inv. & 134,864 & 147,071 & 168,878 & 191,866 & 234,317 & 1.74 \\
\hline & SME Inv. to total Inv. (\%) & 15.94 & 19.68 & 20.44 & 20.85 & 16.00 & 0.06 \\
\hline \multirow[t]{3}{*}{ UBL } & SME Inv. & $35,015.50$ & 35,956 & $26,668.40$ & 21,509 & $30,587.70$ & 0.87 \\
\hline & Total Inv. & 64,830 & 74,199 & 75,807 & 83,269 & 105,261 & 1.62 \\
\hline & SME Inv. to total Inv. (\%) & 54.01 & 48.46 & 35.18 & 25.83 & 29.06 & $(24.95)$ \\
\hline \multirow[t]{3}{*}{$\mathrm{UCB}$} & SME Inv. & $70,246.60$ & $87,670.00$ & $80,598.30$ & $86,219.05$ & $90,910.64$ & 1.29 \\
\hline & Total Inv. & 148,665 & 174,146 & 197,4134 & 223,697 & 261,003 & 1.76 \\
\hline & SME Inv. to total Inv. (\%) & 47.25 & 50.34 & 40.83 & 38.54 & 34.83 & $(12.42)$ \\
\hline
\end{tabular}

Source: Compiled and Calculated from 2013-2017 Corporate Annual Reports 
Table-3: Growth in Agricultural Investments (Agri. Inv.)

\begin{tabular}{|c|c|c|c|c|c|c|c|}
\hline \multirow[t]{2}{*}{ Bank } & \multirow[t]{2}{*}{ Particular } & \multicolumn{5}{|c|}{ Yearly Disbursement (Million BDT) } & \multirow{2}{*}{$\begin{array}{l}\text { Continual } \\
\text { Growth (Times) }\end{array}$} \\
\hline & & 2013 & 2014 & 2015 & 2016 & 2017 & \\
\hline \multirow[t]{3}{*}{$\mathrm{ABBL}$} & Agri. Inv. & 1880 & 2050 & 2910 & 3100 & 3180 & 1.69 \\
\hline & Total Inv. & 140,121 & 177,571 & 209,725 & 218,769 & 229,647 & 1.64 \\
\hline & Agri. Inv. to total Inv. (\%) & 1.34 & 1.15 & 1.39 & 1.42 & 1.38 & 0.04 \\
\hline \multirow[t]{3}{*}{ DBBL } & Agri. Inv. & $1,900.74$ & $1,978.70$ & $2,402.57$ & $2,953.60$ & $4,964.80$ & 2.61 \\
\hline & Total Inv. & 106,423 & 124,423 & 152,270 & 173,398 & 207,257 & 1.95 \\
\hline & Agri. Inv. to total Inv. (\%) & 1.80 & 1.60 & 1.59 & 1.71 & 2.41 & 0.62 \\
\hline \multirow[t]{3}{*}{ DBL } & Agri. Inv. & 1,642 & 1,965 & 2,044 & $1,588.80$ & $2,387.22$ & 1.45 \\
\hline & Total Inv. & 99,596 & 103,131 & 117,840 & 134,689 & 154,017 & 1.55 \\
\hline & Agri. Inv. to total Inv. (\%) & 1.66 & 1.92 & 1.74 & 1.19 & 1.56 & $(0.11)$ \\
\hline \multirow[t]{3}{*}{ EBL } & Agri. Inv. & 829 & 2952.57 & 2944.35 & $6,673.39$ & 7192.54 & 8.68 \\
\hline & Total Inv. & 102,910 & 118,291 & 130,226 & 152,084 & 184,027 & 1.79 \\
\hline & Agri. Inv. to total Inv. (\%) & 0.81 & 2.50 & 2.26 & 4.39 & 3.91 & 3.10 \\
\hline \multirow[t]{3}{*}{ EXIM } & Agri. Inv. & $2,428.70$ & $2,760.20$ & $2,886.40$ & $1,933.30$ & 2968.6 & 1.22 \\
\hline & Total Inv. & 143,847 & 177,937 & 196,311 & 222,155 & 253,803 & 1.76 \\
\hline & Agri. Inv. to total Inv. (\%) & 1.70 & 1.56 & 1.48 & 0.88 & 1.18 & $(0.53)$ \\
\hline \multirow[t]{3}{*}{ IBBL } & Agri. Inv. & 13,074 & 13,199 & 9,716 & 15,425 & 16,944 & 1.30 \\
\hline & Total Inv. & 403,195 & 463,475 & 530,194 & 616,419 & 710,729 & 1.76 \\
\hline & Agri. Inv. to total Inv. (\%) & 3.25 & 2.86 & 1.84 & 2.51 & 2.39 & $(0.87)$ \\
\hline \multirow[t]{3}{*}{ IFIC } & Agri. Inv. & 773.4 & 230 & $1,632.70$ & $3,006.81$ & 3,371 & 4.36 \\
\hline & Total Inv. & 84,110 & 102,282 & 123,269 & 137,118 & 179,264 & 2.13 \\
\hline & Agri. Inv. to total Inv. (\%) & 0.92 & 0.22 & 1.32 & 2.19 & 1.88 & 0.96 \\
\hline \multirow[t]{3}{*}{ JBL } & Agri. Inv. & 1199 & 1073.8 & 1816.4 & $13,36.64$ & 1948.84 & 1.63 \\
\hline & Total Inv. & 67,669 & 77,900 & 87,252 & 117,100 & 142,253 & 2.10 \\
\hline & Agri. Inv. to total Inv. (\%) & 1.78 & 1.39 & 2.09 & 1.15 & 1.38 & $(0.41)$ \\
\hline \multirow[t]{3}{*}{ MBL } & Agri. Inv. & 2217.9 & $1,785.80$ & $2,202.19$ & 4111.28 & 3776.87 & 1.70 \\
\hline & Total Inv. & 97,689 & 117,060 & 126,339 & 150,913 & 199,661 & 2.04 \\
\hline & Agri. Inv. to total Inv. (\%) & 2.27 & 1.53 & 1.74 & 2.72 & 1.89 & $(0.38)$ \\
\hline \multirow[t]{3}{*}{ NBL } & Agri. Inv. & - & $1,811.28$ & $1,651.85$ & $2,287.16$ & $3,494.22$ & 1.93 \\
\hline & Total Inv. & 151,099 & 172,965 & 186,179 & 209,929 & 248,467 & 1.64 \\
\hline & Agri. Inv. to total Inv. (\%) & - & 1.05 & 0.89 & 1.09 & 1.41 & 0.36 \\
\hline \multirow[t]{3}{*}{ SBL } & Agri. Inv. & 603.33 & 760.87 & $1,644.59$ & & $3,541.59$ & 5.87 \\
\hline & Total Inv. & 134,864 & 147,071 & 168,878 & 191,866 & 234,317 & 1.74 \\
\hline & Agri. Inv. to total Inv. (\%) & 0.45 & 0.52 & 0.97 & 0.00 & 1.51 & 1.06 \\
\hline \multirow[t]{3}{*}{ SIBL } & Agri. Inv. & 745 & 2,814 & 3,769 & 5,982 & 5,234 & 7.03 \\
\hline & Total Inv. & 85,707 & 84,062 & 96,835 & 122,998 & 158,668 & 1.85 \\
\hline & Agri. Inv. to total Inv. (\%) & 0.87 & 3.35 & 3.89 & 4.86 & 3.30 & 2.43 \\
\hline \multirow[t]{3}{*}{ UBL } & Agri. Inv. & $1,186.30$ & $1,691.22$ & $1,807.50$ & 209.08 & 219.5 & 0.19 \\
\hline & Total Inv. & 64,830 & 74,199 & 75,807 & 83,269 & 105,261 & 1.62 \\
\hline & Agri. Inv. to total Inv. (\%) & 1.83 & 2.28 & 2.38 & 0.25 & 0.21 & $(1.62)$ \\
\hline \multirow[t]{3}{*}{$\mathrm{UCB}$} & Agri. Inv. & & 2,763 & 2,787 & 2608 & 5,540 & 2.01 \\
\hline & Total Inv. & 148,665 & 174,146 & 197,4134 & 223,697 & 261,003 & 1.76 \\
\hline & Agri. Inv. to total Inv. (\%) & - & 1.59 & 1.41 & 1.17 & 2.12 & 0.54 \\
\hline
\end{tabular}

Source: Compiled and Calculated from 2013-2017 Corporate Annual Reports 
Table-4: Environment Friendly (EF) Investments (Inv.) Pattern

\begin{tabular}{|c|c|c|c|c|c|c|c|}
\hline \multirow[t]{2}{*}{ Bank } & \multirow[t]{2}{*}{ Particular } & \multicolumn{5}{|c|}{ Yearly Disbursement (Million BDT) } & \multirow{2}{*}{$\begin{array}{l}\text { Continual } \\
\text { Growth } \\
\text { (Times) }\end{array}$} \\
\hline & & 2013 & 2014 & 2015 & 2016 & 2017 & \\
\hline \multirow[t]{3}{*}{ DBBL } & EF Inv. & - & - & - & $32,815.62$ & $26,980.44$ & 0.82 \\
\hline & Total Inv. & 106,423 & 124,423 & 152,270 & 173,398 & 207,257 & 1.95 \\
\hline & $\begin{array}{l}\text { EF inv. to total Inv. } \\
(\%)\end{array}$ & - & & - & 18.93 & 13.02 & $(5.91)$ \\
\hline \multirow[t]{3}{*}{ DBL } & EF Inv. & - & - & - & - & 6461.85 & \\
\hline & Total Inv. & 99,596 & 103,131 & 117,840 & 134,689 & 154,017 & 1.55 \\
\hline & $\begin{array}{l}\text { EF inv. to total Inv. } \\
(\%)\end{array}$ & - & - & - & - & 4.20 & \\
\hline \multirow[t]{3}{*}{ EBL } & EF Inv. & 22,265 & 16,497 & 22,265 & - & $25,633.00$ & 1.15 \\
\hline & Total Inv. & 102,910 & 118,291 & 130,226 & 152,084 & 184,027 & 1.79 \\
\hline & $\begin{array}{l}\text { EF inv. to total Inv. } \\
(\%)\end{array}$ & 21.64 & 13.95 & 17.10 & - & 13.93 & $(7.71)$ \\
\hline \multirow[t]{3}{*}{ EXIM } & EF Inv. & $14,197.10$ & $18,282.80$ & $24,243.90$ & $36,837.20$ & $49,024.40$ & 3.45 \\
\hline & Total Inv. & 143,847 & 177,937 & 196,311 & 222,155 & 253,803 & 1.76 \\
\hline & $\begin{array}{l}\text { EF inv. to total Inv. } \\
(\%)\end{array}$ & 9.87 & 10.27 & 12.35 & 16.58 & 19.32 & 9.45 \\
\hline \multirow[t]{3}{*}{ IBBL } & EF Inv. & 44457 & 54751.12 & 78000.09 & 90958 & 97476 & 2.19 \\
\hline & Total Inv. & 403,195 & 463,475 & 530,194 & 616,419 & 710,729 & 1.76 \\
\hline & $\begin{array}{l}\text { EF inv. to total Inv. } \\
(\%)\end{array}$ & 11.03 & 11.81 & 14.71 & 14.76 & 13.71 & 2.69 \\
\hline \multirow[t]{3}{*}{ IFIC } & EF Inv. & 1723.83 & 439.28 & - & 777.66 & $8,023.99$ & 4.65 \\
\hline & Total Inv. & 84,110 & 102,282 & 123,269 & 137,118 & 179,264 & 2.13 \\
\hline & $\begin{array}{l}\text { EF inv. to total Inv. } \\
(\%)\end{array}$ & 2.05 & 0.43 & - & 0.57 & 4.48 & 2.43 \\
\hline \multirow[t]{3}{*}{ JBL } & EF Inv. & 3234.87 & - & 3451.24 & - & 1407.42 & $(0.44)$ \\
\hline & Total Inv. & 67,669 & 77,900 & 87,252 & 117,100 & 142,253 & 2.10 \\
\hline & $\begin{array}{l}\text { EF inv. to total Inv. } \\
(\%)\end{array}$ & 4.78 & - & 3.96 & - & 0.99 & $(3.79)$ \\
\hline \multirow[t]{3}{*}{ MBL } & EF Inv. & 172.07 & 100 & 12.5 & 265 & 439.42 & 2.55 \\
\hline & Total Inv. & 97,689 & 117,060 & 126,339 & 150,913 & 199,661 & 2.04 \\
\hline & $\begin{array}{l}\text { EF inv. to total Inv. } \\
(\%)\end{array}$ & 0.18 & 0.10 & 0.01 & 0.18 & 0.23 & 0.05 \\
\hline \multirow[t]{3}{*}{ NBL } & EF Inv. & - & 938.7 & 698.89 & 2262.646 & 3377.08 & 3.60 \\
\hline & Total Inv. & 151,099 & 172,965 & 186,179 & 209,929 & 248,467 & 1.64 \\
\hline & $\begin{array}{l}\text { EF inv. to total Inv. } \\
(\%)\end{array}$ & - & 0.54 & 0.38 & 1.08 & 1.36 & 0.82 \\
\hline \multirow[t]{3}{*}{ SBL } & EF Inv. & 4.3 & 13407.8 & 17532.5 & & 14,100 & 3279.07 \\
\hline & Total Inv. & 134,864 & 147,071 & 168,878 & 191,866 & 234,317 & 1.74 \\
\hline & $\begin{array}{l}\text { EF inv. to total Inv. } \\
(\%)\end{array}$ & 0.00 & 9.12 & 10.38 & 0.00 & 6.02 & 6.01 \\
\hline \multirow[t]{3}{*}{ UBL } & EF Inv. & 12.39 & 186.7 & 343.22 & 82.18 & 469.98 & 37.93 \\
\hline & Total Inv. & 64,830 & 74,199 & 75,807 & 83,269 & 105,261 & 1.62 \\
\hline & $\begin{array}{l}\text { EF inv. to total Inv. } \\
(\%)\end{array}$ & 0.02 & 0.25 & 0.45 & 0.10 & 0.45 & 0.43 \\
\hline \multirow[t]{3}{*}{$\mathrm{UCB}$} & EF Inv. & - & - & $8,533.22$ & 1846.5 & 419.98 & 0.05 \\
\hline & Total Inv. & 148,665 & 174,146 & 197,4134 & 223,697 & 261,003 & 1.76 \\
\hline & $\begin{array}{l}\text { EF inv. to total Inv. } \\
(\%)\end{array}$ & - & & 4.32 & 0.84 & 0.17 & $(4.16)$ \\
\hline
\end{tabular}

Source: Compiled and Calculated from 2013-2017 Corporate Annual Reports 
Table-5: EPS Growing Pattern

\begin{tabular}{|c|c|c|c|c|c|c|}
\hline \multirow[t]{2}{*}{ Bank } & \multicolumn{5}{|c|}{ Yearly Distribution (Million BDT) } & \multirow{2}{*}{$\begin{array}{l}\text { Continual } \\
\text { Growth (Times) }\end{array}$} \\
\hline & 2013 & 2014 & 2015 & 2016 & 2017 & \\
\hline $\mathrm{ABBL}$ & 1.69 & 2.1 & 2.12 & 1.72 & 0.04 & -1.65 \\
\hline BRAC & 2.47 & 3.19 & 3.43 & 4.55 & 6.07 & 3.60 \\
\hline$\overline{D B B L}$ & 10 & 11 & 15.1 & 8.9 & 12.3 & 2.30 \\
\hline DBL & 3.56 & 3.57 & 2.3 & 2.13 & 2.07 & -1.49 \\
\hline EBL & 4.2 & 3.45 & 3.63 & 3.78 & 3.26 & -0.94 \\
\hline EXIM & 1.65 & 1.93 & 1.55 & 2.08 & 2.26 & 0.61 \\
\hline IBBL & 3.4 & 2.49 & 1.88 & 2.77 & 2.91 & -0.49 \\
\hline IFIC & 3.07 & 3.07 & 1.76 & 1.38 & 2.02 & -1.05 \\
\hline JBL & 2.53 & 2.19 & 2.67 & 3.06 & 3.29 & 0.76 \\
\hline MBL & 2.68 & 1.61 & 1.88 & 3.01 & 3.89 & 1.21 \\
\hline NBL & 1.36 & 1.55 & 2.24 & 2.35 & 1.98 & 0.62 \\
\hline SBL & 3.68 & 4.18 & 3.35 & 2.66 & 1.27 & -2.41 \\
\hline SIBL & 1.78 & 1.02 & 1.76 & 2.02 & 1.55 & -0.23 \\
\hline UBL & 3.28 & 3.47 & 3.76 & 3.83 & 3.89 & 0.61 \\
\hline $\mathrm{UCB}$ & 3.05 & 3.65 & 3.96 & 2.49 & 2.31 & -0.74 \\
\hline
\end{tabular}

NB: EPS disclosure made aligned with face value of BDT 10

Source: Compiled and Calculated from 2013-2017 Corporate Annual Reports

Table-6: Growth in Pay-out to National Exchequer

\begin{tabular}{|l|r|r|r|r|r|r|}
\hline \multirow{2}{*}{ Bank } & \multicolumn{5}{|c|}{ Yearly Contribution (Million BDT) } & $\begin{array}{l}\text { Continual } \\
\text { Growth } \\
\text { (Times) }\end{array}$ \\
\cline { 2 - 7 } & $\mathbf{2 0 1 3}$ & $\mathbf{2 0 1 4}$ & $\mathbf{2 0 1 5}$ & $\mathbf{2 0 1 6}$ & $\mathbf{2 0 1 7}$ & -0.10 \\
\hline ABBL & 1,974 & 2,719 & 1,489 & 697 & -188 & 1.49 \\
\hline BRAC & 1,778 & 2,072 & 2,186 & 2,688 & 2,647 & 1.30 \\
\hline DBBL & 2,179 & 2,698 & 3,223 & $1,458.90$ & $2,838.00$ & 1.58 \\
\hline DBL & 849.77 & $1,191.84$ & 938.4 & 1,282 & 1,344 & 2.07 \\
\hline EBL & 2268 & 1911.62 & $1,275.56$ & 2,940 & 4,698 & 1.50 \\
\hline EXIM & $1,333.94$ & $1,925.99$ & $1,565.24$ & $1,947.63$ & $2,001.32$ & 1.32 \\
\hline IBBL & $10,963.07$ & $11,465.00$ & $17,392.00$ & $15,342.43$ & $14,424.46$ & 2.16 \\
\hline IFIC & 1,362 & 1,132 & 728 & 870 & 2,946 & 1.17 \\
\hline JBL & 1149.7 & 500.26 & 1843 & $1,013.91$ & $1,349.58$ & 1.04 \\
\hline MBL & 1250 & 1,100 & 1250 & 1,260 & 1300 & 1.33 \\
\hline NBL & 1372.75 & 2477.099 & 2489.222 & $2,855.26$ & $1,826.04$ & 1.02 \\
\hline SBL & $2,573.77$ & $2,519.31$ & $1,644.59$ & 1249.34 & $2,635.45$ & 0.82 \\
\hline SIBL & 1,078 & 29 & 468 & 748.71 & 882.62 & 0.71 \\
\hline UBL & 1,370 & 1,513 & 1,018 & 492.1 & 973.8 & 1.07 \\
\hline UCB & 2,822 & 3,167 & 3,275 & $2,561.25$ & $3,027.50$ & \\
\hline
\end{tabular}

Source: Compiled and Calculated from 2013-2017 Corporate Annual Reports 